\title{
The Effects of Post-conflict
}

\section{Constitutional Designs: the "Ohrid Framework Agreement" and the Macedonian Constitution}

Stefan Andonovski

\section{Abstract}

In regions troubled by ethnic based conflict violence often erupts abruptly and severely. Peacemakers, then, follow unconditional paths to prevent conflict escalation. The article analyzes the ways in which post-conflict constitutional designs shape the state structure through constitutional amendments. Peace agreements as bases for constitutional reform, the article claims, have reformatory but also obstructive implications. Seeing the Ohrid Framework Agreement as a case study, the paper analyzes its implications on the development of the political system in Macedonia. On one side OFA serves as a criterion for the Macedonian Euro-Atlantic integration and a driving force for the creation of a functioning multicultural society. On the other side, the procedural and substantive flaws of the agreement undermine its absorbability in the society. In procedural sense, OFA hindered its own implementation through the used terminology and the drafting process. In substantial sense, agreement's goals and provisions reached beyond the purpose of peace agreements and underestimated the complexity of the conflicting issues at stake.

\section{KEY WORDS:}

constitutional amendments, peace agreement, Ohrid Framework Agreement, inter-ethnic conflict, post-conflict reform 


\section{Introduction}

In regions historically troubled by civil wars and ethnic based conflict violence often erupts abruptly and severely. In such cases, peacemakers and politicians often follow unconditional paths to prevent a conflict from escalating into a full-fledged war. These various paths towards conflict resolution through constitution redesigning have provoked scholars and practitioners to devise "best practice" concepts. It has become increasingly important for practitioners to draw on synthesized conceptual approaches before designing constitutional structures that have long-term implications. Moreover, there is a need for future designs to build on previous successes and avoid missteps. In a rush for "conflict freezing", as it will be discussed in this article, constitutional arrangements contained in peace agreements often underestimate the complexity of conflicting issues at stake, both in goal setting, procedural dynamics and substantial endurance. When setting the goals, agreements ought to realistically target the context. In order for that to be achieved, processes of agreement drafting should include a plethora of societal actors in order to set an agreed upon base for reforms. Conversely, top-down procedures in drafting tend to achieve some, but not all of the goals that have been set. In essence, the lack of actors' participation in the procedural dynamics complicates subsequent implementation phase, which would lack local ownership.

Authors have devised the goals that are usually set in post-conflict constitution designs by analyzing large data pools of post-conflict constitutions and peace agreements. Widner (2008) discusses "three sets of ambitions". The first set entails durability of the agreement, followed by the reduction of violence and increase in civility, which allows for institutionalization of the conflict. The third ambition underlines the importance of agreement's self-enforcement in the future. Bearing in mind that every process varies, there is a wide-spread urge for the design drafting to entail sense of inclusion and trust. "Constitution makers must find a way to reconcile the need to tie in powerful elites with the demand for a consultative process that fosters political dialogue and empowers the people" (Samuels and Hawkins Wyeth 2006). 
In unfolding the argument, the article presents the dilemmas of the the Ohrid Framework Agreement ${ }^{1}$, regarding the limits of the constitutionalinstitutional engineering. In that sense, we analyze the most prominent spheres of influence of the Ohrid Framework Agreement in the Macedonian post-conflict constitutional state structure. The Agreement's widely appreciated as a basis for the creation of a functioning multiethnic society, and a criterion for the Macedonian integration in the EuroAtlantic institutions. However, while the Agreement should be praised for these aspects, its problematic implications should not be underestimated. In procedural sense, the Agreement, through its imprecise terminology hindered its own implementation. Being a peace agreement, OFA determined in detail the processes and provisions of the constitutional remaking, not allowing for an inclusive drafting process. In that way, a political agreement dominated over the only constitutional body that directly represents the citizens in the country. As discussed later, the agreement transcended general goals of peace agreements - to bring about end to violence and allow for institutionalization of conflict - and set forth all-encompassing goals. In substantial sense, the Agreement overestimated the ability of the Macedonian society to absorb its goals and provisions by introducing the paradigm of the "spirit" of the agreement. This has made OFA's implementation prone to political infringements and biased evaluation.

In unfolding the argument, the article describes the socio-political context prior to the conflict of 2001. Then, it analyzes the structural remaking envisioned in the Ohrid Framework Agreement with the constitutional amendments adopted in November, 2001. Subsequently, the article describes the implications of the implemented provisions, both in terms of process and substance. Finally, the argumentation offers a perspective on the possible lessons that can be learned for future post-conflict constitutional designs, as well as some thoughts on the development of the Macedonian political system. 


\section{Macedonia Leading up to the 2001 Conflict}

On 8 September 1991, amidst the socio-political disintegration of Socialist Yugoslavia, Macedonian citizens laid the grounds for an independent Republic of Macedonia through a popular referendum. On 17 November 1991, the Assembly adopted a new constitution, which promoted Macedonia's independence, sovereignty and democratic character. On the international scene, however, the path towards recognition was obstructed, largely because of the problem with neighbors' unwillingness to accept the name of the country².

For ten years, the international community perceived Macedonia as a successful multiethnic model of coexistence. Macedonia was trumpeted a conflict prevention example, when compared to the ethnic cleansing, war crimes, genocides and social destruction in the broader region. Its first president, Kiro Gligorov, labelled Macedonia an "oasis of peace". Being that the demographic structure was complex, Macedonia represented a multiethnic society at its finest. Ethnic Macedonians comprised $65.3 \%$ of the population, ethnic Albanians were $21.7 \%, 3.8 \%$ were ethnic Turks, $2.5 \%$ Romany, ethnic Serbs were $2.1 \%$, and $6 \%$ were in other ethnic groups. (ICG Balkans Report 2001: 109). However, the claims that the conflict in 2001 was unexpected, and that the conflicting issues are to be found exclusively in that year, are misleading. The complexity of the context, which intertwined nations, language, human rights, separatism, historic momentum, spillover and Balkan heritage, sadly was to be understood only after the conflict.

There are numerous underlying and mobilizing factors that lead to the conflict in 2001, but the domestic and foreign actors were not eager to act preventively ${ }^{3}$. Without comprehensively analyzing all the issues that drove the conflict, it is important to note the ones that were targeted with the Agreement. First, the 1991 Constitution and the political discourse were predominantly ethnocentric, which set the terrain for institutional

2 More on the name issue see Shea ,J,. 1997. Macedonia and Greece: The Struggle to Define a New Balkan Nation. Jefferson, North Carolina: McFarland \& Company, Inc.

3 On the underlying factors of the conflict and the conflict itself, a comprehensive view can be seen in Phillips, J., 2002. Macedonia: Warlords and Rebels in the Balkans. London: I.B. Tauris. 
and structural injustices. The Constitution, while establishing a liberal democracy and proclaiming fundamental human rights and freedoms, was insufficiently inclusive for the ethnic minorities. That lack of inclusion was especially felt in the realm of the use of another language in official communication, which was allowed only where other nationalities were a large majority strictly on local level. Also, the central position of the Macedonians as a constituent people of the country was seen as ethnocentric, a notion that was invigorated by the promotion of the Macedonian Orthodox Church as a confessional leader of the country. As a result, Albanian political parties boycotted the Referendum and the constitution adoption. They organized a parallel referendum asking for autonomy of Western Macedonia. The ethnic majority, overwhelmed by the historic moment of the Macedonian independence, was not alarmed by the isolation of the Albanian population. Only in the aftermath of the conflict it was understood that the Constitution was embedded with these structural injustices, making it a casus belli.

Second, there was a systemic fault in the structure of state institutions, which accentuated the social injustices. The public administration was not designed to represent the societal multiethnic conglomerate, especially in the use of language, education, and structure. There were issues with the participation of Albanians in the school system and their right to mothertongue education, with an accent to the universities. The institutional representation of Albanians was also problematic when combined with the inability to use the Albanian in official institutional communication, and the claims for discrimination on ethnic lines. This led to serious countrywide protests when the government proclaimed the Tetovo Faculty of Pedagogy illegal, and violently stopped the peaceful protests in the towns of Tetovo and Gostivar. The clashes with the security forces led to imprisonment of mayors and other prominent Albanian leaders ${ }^{4}$. These outbursts of violence and the lack of institutional response, further eroded the political legitimacy of the state institutions, creating mistrust among large portion of the population.

Third, the spillover effect from the 1999 Kosovo war and the refugee crisis emerged as extra-constitutional drivers. Former fighters from the Kosovo Liberation Army (UCK), unsatisfied with the conclusion of the war

4 More on the problematic issues during the transition period in the 1990s can be seen at http://republika.mk/348197 
on Kosovo, expressed their irredentist and overtly nationalistic territorial claims. Their proclaimed goal was the "re-creation of Great Albania" ("llirida"), which would include the western part of Macedonia, Albania, Kosovo and parts of Montenegro 5 .

The conflict started in the spring of 2001, when the so called National Liberation Army (NLA) occupied small villages in western Macedonia. The Albanian rebels at first demanded territorially cleansed Albanian towns and villages, and subsequently pivoted towards pledges for human rights and freedoms. When in April the NLA killed a number of Macedonian soldiers, a severe crisis started unfolding. Macedonian security forces, in order to disperse the terrorist groups, countered with heavy artillery in the conflicting pockets. Ethnic Macedonians, outraged by NLA's claims for "liberated territories" and the killings, took on innocent ethnic Albanians and religious buildings in cities where Macedonians were the dominant population'. As the crisis escalated, it was clear that the Macedonian authorities are unable to swiftly outgun the NLA. The international community unanimously supported the elected government, identifying the rebels as "bunch of murderous thugs whose objective is to destroy a democratic Macedonia"". The peak of the escalation happened in June, when the NLA captured the village of Arachinovo, only few kilometers away from the capital Skopje, the international airport and the NATO (KFOR) bases. After a combined actions by the Macedonian police and the army, the NLA remained in the village, while their cells throughout the country counter-attacked the security forces. This prompted the international community to intervene in order to prevent further escalation. Javier Solana, then EU High Representative for Common Foreign and Security Policy, arrived in Skopje in order to expedite a negotiation process before the conflict turned into a full-fledged civil war.

5 In a televised interview, one of the activists in KLA and NLA claimed that The Kosovo KLA had other goals, i.e. unification of all the territories where the Albanians live. But international officials, according to them, especially the Americans, cut it off and prevented them from flying outside the borders of a single state. The analysis can be seen at http://bit.ly/2HtkUpS

6 More on the issue can be seen at http://www.nytimes.com/2001/06/07/world/macedonia-threatens-to-declarestate-of-war-against-rebels.html

7 Most prominent in his discourse was the NATO Secretary General, Lord George Robertson. More on the issue can be seen at http://news.bbc.co.uk/2/hi/europe/1317049.stm 


\section{The Ohrid Framework Agreement (OFA)}

The negotiations included a plethora of international actors, who created the necessary procedural dynamics needed for the conflict resolution. The mediators, formally facilitators, in the political negotiations included James Pardew, a US diplomat, and a representative from the EU - Francois Leotard. The facilitation process was assisted by Solana, the OSCE representative Robert Frowick, and the Dutch diplomat Pieter Feith. While Pardew and Leotard negotiated the issues with the Macedonian political actors, Feith and Frowick acted as intermediaries between the NLA rebels and the officials. The international community put a strong pressure on all parties to find an alternative to the escalating violence. NATO, OSCE and EU representatives combined strategies of support and shaming and blaming in order to induce the actors to accept the nonviolent alternative of dealing with conflicting issues.

On 13 August 2001, in Skopje, the Macedonian political representatives signed the Agreement, after prolonged and intense negotiations in Ohrid. Although a compromise between the two parties of the conflict - Macedonian security forces and the National Liberation Army (NLA) OFA's signatories were the President of the Republic of Macedonia, and the leaders of the two predominant parties from the Macedonian and the Albanian block. The international community representatives, who drafted OFA, acted as witnesses of the signing ceremony.

"The Ohrid Framework Agreement is structured around four areas: Securing peace (Articles 1 and 2); Decentralization and use of emblems (Articles 3 and 7); Regulations relating to minorities (Articles 4 and 5); and Education and use of languages (Article 6)" (Czymmeck and Viciska 2011 : 75). Moreover, it contains three annexes that regulate in detail the amendments of the constitution, the needed changes in laws and the implementation of the Agreement.

The objectives and the principles of the Agreement were set highly. OFA aimed not only to stop the erupting violence, but to secure respect for minorities, integration of the country in the European Union and NATO, 
and democratic development of the country in different spheres. The preamble of the Agreement, containing those goals, stated:

"The following points comprise an agreed framework for securing the future of Macedonia's democracy and permitting the development of closer and more integrated relations between the Republic of Macedonia and the Euro-Atlantic community. This Framework will promote the peaceful and harmonious development of civil society while respecting the ethnic identity and the interests of all Macedonian citizens." (Ohrid Framework Agreement 2001: Preamble)

From the Preamble it was clear that OFA's first aim was to secure Macedonia's existence. Then, the goal was to guarantee and develop its democratic future by assisting its integration to the Euro-Atlantic institutions and promoting ethnic diversity. Evidently, the goals of the peace framework strived for more than peace and prosperity. They envisioned to add value to the democratic ambient in the country, protect human rights, promote civil society, and drive the international integration of the country. Additionally, using a quid pro quo model, the Agreement draw on the demands of the two conflicting parties. Authors suggest that "the Ohrid Peace Agreement is a compromise: Macedonia is unitary state ... but ethnic Albanians are increasing their influence, especially on the local level, and have obtained a large right of veto in the Parliament" (Maleska 2005). On one side, the Agreement established that democratic reforms in the country can only be made by political means On the other one, it stressed the importance of the mechanisms for power-sharing and inclusion of minorities as the only path towards a functioning democracy - "There are no territorial solutions to ethnic issues." (Ohrid Framework Agreement 2001: Article 1.2). Based on Macedonian demands, the Agreement recognized the territorial unity of the country within its borders and its sovereignty. As a counter step, the Albanian side gained high degree of autonomy by broadening the rights for local selfgovernance and decentralizing state powers. Finally, the Agreement stressed the conceptual significance of non-discrimination and equal treatment of all, established a principle of bi-ethnic consensus on sensitive questions, and pledged for substantial foreign aid for full implementation of its complex provisions. Essentially, the Agreement generally followed Lijphard's consociational model of democracy, without engaging in 
federalization and bicameralism - "1. Executive power sharing in broad coalition cabinets; 2. Executive-legislative balance of power without resignation of the government; 3. Multiparty system (not two-party); 4. Proportional representation; 5. Interest-group corporatism; 6. Federal and decentralized government. The power is shared between the central (federal) government and the federal units in the composition thereof; 7. Strong bicameralism; 8. Constitutional rigidity; 9. Judicial control (revision); 10. Independence of central bank". (Lijphart 2003: 97-105)

The goals set forth in the preamble of the agreement transcend the pure power-sharing model and pledge for cooperation among actors for reaching common goals, especially underlining the goals of Euro-Atlantic integration and promotion of civil society. That meant that the Ohrid Framework Agreement offered a blend between a purely consociational and an integrative model. It set consociational features as a basis for the new constitutional structures, but also promoted integrative aspects of common trans-ethnical goals. However, the goals that were envisioned went beyond the aspirations which drafters of peace agreements usually set in post-conflict constitutional designs, which focus on the secession of violence, transformation of conflict and implementability of a durable agreement (Widner 2008). By adding the aspiration for Euro-Atlantic integration and the development of civil society as a common goal for all the signatories, the Agreement paved the way for a broader reading of its purpose in the political system and introduced its intangible "spirit".

\section{Constitutional amendments}

The Macedonian Assembly, by November 2001, passed the demanded amendments to the Constitution, drawing on the provisions stated in the Annex A of the OFA. The most contested issue was the amendment to the Preamble of the constitution, as well as the amendments on the voting procedures, the institutional representation of minorities, official use of languages, religious organizations, the national heritage, the functioning of fundamental institutions, and the provisions that regulate the local selfgovernment. 
Amendment 4 of the constitution modified a crucial component of the preamble - the concept of national state. The 1991 Constitution preamble stated that "...[M] acedonia is established as a national state of the Macedonian people, in which full equality as citizens and permanent co-existence with the Macedonian people is provided for Albanians, Turks, Vlachs, Romanies and other nationalities living in the Republic of Macedonia". This mono-national formula did not consider more than $30 \%$ of the population in the country as constituent people. Therefore, based on demands from the Albanian signatories, the Agreement entailed the civic concept, not specifying an ethnicity. Therefore, Annex A of the Agreement begins with: "The citizens of the Republic of Macedonia, taking over responsibility for the present and future of their fatherland,..." This version of the preamble embraced the concept of individual rights. However, this approach was in contrast with collective and communities' rights conceptualized as a general rule in the agreement. According to some scholars, the Macedonian people and nation disappeared as an ethnic category, as well as a sociological one. (Skaric 2004) This "citizen approach" was severely criticized by politicians, experts and the general public ${ }^{8}$. After a prolonged debate, an intermediate solution was achieved. As such, Amendment 4 contains nation, civic and binational state elements, stating:

"The citizens of the Republic of Macedonia, the Macedonian people, as well as citizens living within its borders who are part of the Albanian people, the Turkish people, the Vlach people, the Serbian people, the Romany people, the Bosniak people and others..."

The promotion of several constituent peoples of the country and the primary position for the Macedonian citizens as a majority is a democratic achievement worth noting. It stresses the rights of the citizens accompanied with the rights of the communities, making the ethnicities equally important pillars of the country. However, the list of communities is incomplete. The term "others" excludes more than 20 registered minorities, which in the subsequent years expressed their grievances of not being part of the constituent conglomerate.

8 More on the discussion for the amendments to the Preamble see at http://bit.ly/21l cxyW 
The second structural transformation is the voting procedure, which established a new form of minority veto. Amendment 18, together with amendments that regulate the spheres of interest to the communities, added an additional obstacle to the absolute majority vote $150 \%$ of the representatives plus one), and the qualified majority vote (two-thirds of the representatives). According to these amendments, "a law that affects the communities of the country shall require a two-thirds majority vote [or an absolute vote] of the total number of representatives, within which there must be a majority of the votes of the total number of representatives who belong to the communities not in the majority of the population of Macedonia9." The procedure would affect future amendments to the constitution and laws that regulate: local self-government organization; the use of language, education, personal documentation, culture and use of symbols; the fundamental values of the country; the equality of citizens under the law; the freedom of religious confession; the protection of identity; the protection of the national heritage; election of Public Attorney (Ombudsman), the Council for Inter-Ethnic Relations, the Security Council of the Republic of Macedonia, the Judicial Council and the Constitutional Court judges. The voting procedures amendments were to ensure that there could be no "tyranny of the majority" when the Assembly decides on questions that are sensitive to the ethnic minorities. Some scholars feared that this amendment could turn into a "tyranny of the minorities" (Skaric, Siljanovska-Davkova 2009). However, this fear was proved unfounded, because the new voting procedure has enabled an inclusive debate among representatives on sensitive issues, but has not caused major blockades on crucial issues.

The third substantial sphere where the Ohrid Framework Agreement brought a change was the use of languages on central and local level. According Amendment 5 of the Constitution, the official language of the country is Macedonian, which shall be used within the whole territory of the country and international correspondence. In addition, any language spoken by 20 percent of the population is also an official language according to that article of the constitution. The 20 percent threshold, a function of demographics and not of symbolic recognition of status, meant that Albanian was the only other language which was granted a tacit officialization. The use of the second official language was to be in

9 Constitution of the Republic of Macedonia: Amendments 10, 11, 12, 13, 14, 15, 16, 18. 
spheres of concern for the minorities, such as: issuing personal documents, using the language in communication with the public administration, and education. The change in this sphere is with regards to the percentage and the scope of the usage, decreasing the threshold to 20 percent from the former 50 percent. However, the scope of the usage was left for interpretation, which nowadays causes disturbances to the Macedonian political system. The imprecision in the article allowed the parliamentary majority to propose law extending the use of the Albanian language in all spheres, making it a second official language in all institutional correspondence. This law calls upon the right for a second official language given by the Ohrid Framework Agreement and Agreement's importance for the integration to the European Union. As a result, the Law is proposed as a law that integrates the Macedonian legal system with the one of the European Union ${ }^{10}$. The opposition coalition and the President, in an attempt to block the adoption of the law, put a suspensive veto and filed more than 30,000 amendments, stating Law's unconstitutionality and the violation of OFA's provisions ${ }^{11}$. This lack of understanding between the societal actors demonstrates that the Agreement is prone to various political interpretation and shows the conflicting directions in which the Agreement can be implemented.

The fourth sphere lies in the concept of equitable representation in all public administration agencies, which became part of the fundamental Constitutional values. "The purpose the Amendment 6 was to reflect the ethnic structure of the population in the central government and the public life in general" (Skaric, Siljanovska-Davkova 2009: 176). In paragraph 4.2. of the OFA it is stipulated that "Laws regulating employment in public administration will include measures to assure equitable representation of communities in all central and local public bodies and at all levels of employment within such bodies, while respecting the rules concerning competence and integrity that govern public administration." The reform allowed for an increased access of disadvantaged communities to public administration jobs. However, the implementation of this provision, as discussed later in the article, negatively affected the professionalization and modernization of the public administration.

10 The full proposal can be found on http://bit.ly/2rlWEki

11 The President put a veto on the adopted law claiming that it infringed articles of the constitution and had other procedural and substantial anomalies. For full review of the veto see http://pretsedatel.mk/mk/201 1-06-17-09-5507/201 1-07-19-10-40-39/4754.html 
The fifth transformation, which includes Amendments 7 and 9 of the Constitution, protects the freedom of religious thought and expression of religious beliefs. Amendment 7 begins by setting an equal footing for the religious organizations: "The Macedonian Orthodox Church, as well as the Islamic Religious Community in Macedonia, the Catholic Church, Evangelical Methodist Church, the Jewish Community and other Religious communities and groups are separate from the state and equal before the law". Furthermore, Amendment 9 obliges the state to "guarantee[s] the protection, promotion, and enhancement of the historical and artistic heritage of Macedonia and all communities in Macedonia and the treasures of which it is composed, regardless of their legal status". These two amendments promote the social inclusion of the different communities and religious groups in the country, respecting their diversity and historical and cultural heritage. By creating a Committee for InterCommunity Relations, the Assembly strengthens the focus on intercultural dialogue. Committee's obligation is to recommend solutions to the Assembly for inter-ethnic questions.

Finally, Amendments 16 and 17 regulate the voting procedure and the scope of functions of the local self-government. These provisions represent a basis for the development of a decentralized governing system on a local level. The amendments ensured the direct participation of the citizens in the functioning of their municipalities, and created an opportunity for making relevant decisions by the people concerned.

The complexity of the constitutional amendments and their effects are a widely debated topic. ${ }^{12}$ Scholars have predominantly followed a path of unconditional appraisal for the constitutional reform derived from the Ohrid Agreement. It is clear that the agreement, which has brought a stable peace to Macedonia in the last seventeen years, remains to be the base for amicable inter-ethnic communication and social inclusion. However, some of the procedural and substantial flaws have not been analyzed so far. With a goal to add value to the discussion, the article critically observes some of the crucial implications of the agreement for the Macedonian political system. The idea is to underline the prospects

12 See Beiber F. Power Sharing and the Implementation of the Ohrid Framework Agreement. (2008) Skopje: Friedrich Ebert Stiftung, Risteska M, Daskaloski Z (eds) One Decade after the Ohrid Framework Agreement: Lessons (to be) Learned from the Macedonian Experience (2011), Skopje: Friedrich Ebert Stiftung and Center for Research and Policy Making. 
for the implementation of the Agreement in subsequent years, and to derive some lessons for similar endeavors.

\section{Implications of the constitutional amendments}

The implications of the constitutional amendments are a deeply contested issue among the Macedonian and Albanian population and political elites. In political discussions, the agreement is seen as a driver for beneficial reforms by some of the Albanian political entities, while others stress its inability enforce the demanded set of transformations. In the Macedonian political sphere the Agreement is seen rather deterministically, from two extreme viewpoints. One percentage of the population view it as an act of treason, and others have considered OFA a frame for building a sustainable multiethnic society with equal treatment for every citizen. However, the complexity of the Ohrid Framework Agreement demands a detailed and multi-pronged analytical perspective. Therefore, in order to draw practical solutions it is essential to understand the formal and substantial implications of OFA.

In perspective, the implementation of both Agreement's articles and principles is a crucial criterion for the Macedonian integration in the European Union and NATO. According to the European Commission, "[t]he Ohrid Framework Agreement remains an essential element for democracy and rule of law in the country" (EC Progress Report 2012). Therefore, the implementation of the Agreement is the mechanism through which Macedonia can adhere to the EU Copenhagen political criteria, which require "stability of institutions guaranteeing democracy, the rule of law, human rights and respect for and protection of minorities"13. By strengthening the minority rights, the society has embraced a dynamic approach of building modern multicultural democratic structure. The Assembly has undertaken a plethora of measures to protect minorities with a positive long-term effect on their integration. Today, it is clear that the agreement has fulfilled the primary purpose - to establish peace and

13 Accession criteria (Copenhagen criteria) - http://eur-lex.europa.eu/summary/glossary/accession_criteria_ copenhague.html 
to end the violent conflict. By providing inclusive institutional procedures, it has offered basis for development of human rights and transformation of conflict.

However, there are three debatable aspects in terms of the procedural complexities in the Agreement and its formal endurance. Firstly, a political agreement written in English was used to amend a constitution adopted in Macedonian, creating serious implementation deficiencies. Secondly, the Agreement forced popularly elected representatives in the Assembly to vote according to the decisions of the signatories. Thirdly, OFA implicitly established a leeway for armed groups in the future to pressure for constitutional rearrangement.

Ohrid Agreement's only authentic version is the one written in American English ${ }^{14}$. In that sense, when drafting the provisions, peace negotiators did not fully take into account the differences between legal terms in the continental and common law systems. In accordance with the 1991 Constitution, the Ohrid Agreement had to be drafted and adopted in Macedonian, as the only official language in the country. Additionally, the implementation reforms were complicated because the English version was the only agreed basis for interpretation of the provisions and the "spirit" of the agreement. As a result, there have been dilemmas emerging from the differentiation in the meaning of legal terms used in the Agreement. For instance, there was a dispute on the term 'community' because in Macedonian, its meaning is imprecise both conceptually and contextually. The dilemmas were if the term was to represent a local community or an ethnic one. "If it refers to an ethnic community, it is not clear whether it includes the Macedonian ethnic community or only national minorities". (Skaric 2004: 96) Moreover, phrases such as "public body' or 'public institution' have an unspecified meaning. In Macedonia, there are numerous institutions that have public character, including: public enterprises, government agencies, agencies of the local selfgovernment, partnerships etc. However, none of them are differentiated into categories used in the agreement. As it will be discussed later, the Agreement was insistent on the principle of equal representation of communities on all levels in the public life. Yet, with the impreciseness in the wording, it became unclear what are the areas that the term 'public

14 Paragraph 10.2., Ohrid Framework Agreement. 
life' encompasses. In practice, these formal anomalies were a burden to a substantial implementation. Specifically, the anomalies came into practice with the aforementioned Law on the use of language spoken by $20 \%$ of the population, where the use of the Albanian language is extended to all public areas. Those public areas are numbered in the law, but the scope of the usage remained unclear. There is a continued debate if the areas would include private companies which affect public sectors, private cultural and health facilities, private universities, etc. Such ambiguity demonstrates that the legal terminology used in the Agreement poses an obstacle to the meaningful implementation.

Another procedural implication is that the provisions of the Agreement forced popularly elected representatives in the Assembly to vote according to the decisions of its signatories, thereby creating an unconstitutional process of constitution amending. The Constitution in Article 61 stipulates that "The Assembly of the Republic of Macedonia is a representative body of the citizens and the legislative power of the Republic is vested in it." More importantly, Article 62 states that "the Representative [in the Assembly] represents the citizens and makes decisions in the Assembly in accordance with his/her personal convictions." Finally, according to Article 68, line 1 and 2, the Assembly is the only constitutional body that is responsible for adopting and changing the constitution, as well as adopting laws and giving an authentic interpretation of laws. OFA disrupted this concept because it proposed changes of the constitution circumventing the Assembly. The signatories agreed on the exact provisions that would be incorporated in the Constitution, stipulated in Annex A and B of OFA. This meant that the representatives had to discuss and amend the constitution, as stated in the Agreement. According to Paragraph 8.1:

"The constitutional amendments attached at Annex A will be presented to the Assembly immediately. The parties will take all measures to assure adoption of these amendments within 45 days of signature of this Framework Agreement."

These provisions represented an obligation for the signatories to pressure their peers in the Assembly in order to assure an adoption of the amendments, flagrantly violating Article 62 of the constitution. This meant 
that a political agreement dominated over the only constitutional body that directly represents the citizens of the country. Without questioning the attitude of the representatives towards the constitutional amendments, the fact that a political decision was made on a "higher" level, constrained the free decision of the popularly elected representatives. This top-down approach did not allow for an inclusive and legal process of constitution amending. In the rush to appease the conflicting sides, the drafters did not allow the elected parliamentary representatives to have a say in the process. The approach also excluded civil society activists, university professors, practitioners and experts. The lack of public debate led to uninformed choices on the new constitutional design, affecting both the quality of the text and the legality of the procedure. Authors argue that "Informed choices are particularly vital in these contexts where peace is fragile, populations are sharply divided, leaders tend to be inexperienced in governance, and traditional checks and balances are likely to be very weak" (Samuels and Hawkins Wyeth 2006). Essentially, exclusion from the drafting process later led to lack of ownership in the implementation phase. Conversely, if there was a phased process envisioned, in which the prime goal would be the secession of violence followed by a prolonged and inclusive debate on the constitutional arrangement, it would have allowed for an all-encompassing constitutional amending procedure. Such process would have guaranteed peace and would have increased the quality of the amendments. Moreover, the inclusion of an aggregate of actors in a fruitful public debate would have led to meaningful participation of all in the implementation phase.As a third procedural implication, OFA implicitly established leeway for armed groups in the future to pressure for constitutional rearrangements. While the Constitution provided a transparent and inclusive amending procedure, OFA tacitly legitimized the use of violence as a way of pressuring the parliament to engage in constitution remaking. Instead of pursuing constitutional transformation through institutionalization of the conflict, the agreement, by honoring rebels' demands, allowed proposals reached with violence to be put into constitutional amendments. This set forth a negative example, using which future rebels and/or terrorists could demand systemic political changes. "The problem appears when it is assessed that the conflict is cost-effective so the nationalist requests are enhanced". (Vasović 2003: 43) In that sense, this critical implication poses a dilemma: Can amendments achieved through violence legitimize the use of force by radical groups for fulfillment of their political agendas? The dilemma was soon put into practice with 
the platforms used by outlaws from the former KLA and NLA during the outbursts of violence in the following years. For example, in the clash with the security forces in Kumanovo in 2015 the terrorists pledged fighting "for the issue of the disintegration of the Ohrid Framework Agreement and the alleged discrimination against Albanians in Macedonia ${ }^{15}$." The fact that violence should never be accepted as an instrument for democratization is undermined by the Agreement's unconditional admirers. The political support for groups who use violence to change the political system has shown to be costly, both politically and with regards to human lives and infrastructural destruction. The alternative to the swift top-down approach which includes armed groups' demands, would entail preemptive powersharing solutions and secession of violence. Such agreements would be followed by phased democratic changes, strengthened by revoking of the political support to armed radicals by all societal actors.

In substantial sense, the agreement, in its goals and provisions, overestimated the ability of the Macedonian society to absorb the allencompassing solutions. The set goals went beyond stopping and deescalation of the violence. They also entailed securing the democratic future, development of closer and integrated relations with Euro-Atlantic institutions, peaceful and harmonious development of the civil society and respect for ethnic identity and the interests of all. Apart from the goals which were discussed in the previous section, some of OFA's provisions also caused practical problems in their implementation. Here, we analyze the implication of the aspects such as the selection of public administration and the paradigm of the "spirit" of the Agreement.

Domestic and international actors pushed for expedited implementation of the principle for equitable representation of minorities on all levels of the public administration. Such implementation has demonstrated the unpreparedness of the Macedonian society to "absorb" the Agreement. Orlovic asserts that "Proportional representation, although essentially good, through allocation of quotas doubles the administrative posts and public expenditures". (Orlovic 2015) The Agreement itself, in Annex C, regulated the process of employment of the minority communities, stating that "[a]s initial steps [...] the parties [are] committed to ensuring that 500

15 One of the leaders of the group - Commander Malisheva-wrote a letter from the prison in Stip explaining the purpose of their entrance to Kumanovo and the organized clash against the Macedonian security forces. More on the issue in Macedonian see at http://bit.ly/2qX4LPn 
new police officers from communities not in the majority in the population of Macedonia would be hired and trained by July 2002, and 500 additional such officers will be hired and trained by July 2003". Since the Agreement, minority communities' representation has been increased on all levels of the public administration, but the full demands have not been met. Authors argue that the trend of "inclusion of Albanians in the public institutions will have to be continued, because of the imbalance between the number of the employed and the number of persons belonging to the Albanian community in Macedonia". (Skaric 2004: 104) However, the employment on ethnic basis contradicts the criterion for professionalization of the public administration, set in the platform for EU integration. Authors comment that jobs in public institutions have been awarded to party loyalists on both sides, replacing more qualified professionals. "Hiring Albanians also risks becoming a "box ticking exercise" in which many new employees have no clearly defined job description, office or equipment" (CGE Report 2011: №212).

According to the Ministry of Administration, on 31 December 2016, 129,653 people were working in one of the 1,291 public institutions in Macedonia (Yearly Report on the employed in the public sector 2017: 28). With more than $6 \%$ of the population employed in the public administration, there is a clear lack of capacity of the administration to perform its primary function - to serve the citizens. This implication demonstrates that the Agreement can only be absorbed if the society enters an effective process of modernization. The circulus vitiosus can be broken only by solid economic progress, driven by professionalization of the workforce. Such progress would be driven by the innovative measures in the private sector, which should remain the primary employer. Therefore, it is essential for OFA to inspire this trend, not to be its counterpart.

Regarding the "spirit" of the Agreement, there have been two contesting approaches. On one side, a more legalistic approach interprets agreement's provisions as they are written in the text, without deriving mantras and guiding motives. On the other side, there is a broader approach, which reads the agreement through the lenses of a sociopolitical context. This politicization of the provisions and their broad interpretation as a source of constitutional law, further drives the ethnic polarization in the society. There are two most evident examples. First, in 
the last presidential elections, the ruling political party from the Albanian block asked for a concept of consensual election of the president of the country, in line with, according to them, the spirit of consensual democracy envisioned in OFA. Until now, the president is elected on direct popular elections with the majority of votes of all citizens, as regulated by the constitution. The party, DUI, stated that it would not legitimize the elected president because of the lack of votes from the Albanian community. Meeting their demands for consensual election would require new amendments to the constitution, something that was not agreed in OFA. Second example of such extension of OFA's spirit was evident early in 2017, when Albanian leaders from Macedonia signed the so called "Tirana Platform", based on the spirit of the Ohrid Framework Agreement ${ }^{16}$. Under the auspices of the Albanian prime minister, the signatories pledged for a bi-national reengineering of the constitution. The redesigning would be accompanied with the use of the Albanian language as an official constitutional language, including its use in the army, on state emblems, its international use Finally, changes were demanded in the public finances regarding municipalities, affirmative measures for financing Albanians in the cultural institutions, creation of central institutions for the promotion of the Albanian language etc. This type of extending the "spirit" of the agreement to all forms of elections and decision-making complicates the Macedonian political future. In essence, insisting on the autonomous power of the Agreement and its superordinate position over the constitution, undermines the principle of rule of law. On the other hand, the rule of law represents a principle without which there can be no meaningful democratization of the political system and the society in general.

Rights based solely on ethnic belonging further drive the polarization of the people on ethnic lines. This threatens severe division within the society. Some state that the concept "[is] rather divergence and separation than integration" (Orlovic 2015). This divergence starts from elementary schools, affects the secondary education, and peaks on universities. The strict implementation of mother-tongue education principle in separate schools, divides cities and communities. Albanians study in their own elementary schools, graduate from universities where teaching is exclusively in Albanian, which significantly decreases the

16 The full text of the "Tirana Platform" can be found at http://netpress.com.mk/wp-content/uploads/2017/03/1 AB.jpg 
communication with Macedonian peers, friends and neighbors. This mono-ethnic educational approach hinders social cohesion from early age, and decreases the personal contact. Some argue that "in many cases, the formal organization of power along identity or ethnic lines seems to entrench the divisions that fueled the conflict, rather than ameliorate them, and divisions appear to become radicalized during the power-sharing phase" (Samuels and Hawkins Wyeth, 2006). Essentially, what Macedonia needs is an inclusive concept for all the citizens, which accepts and promotes different nationalities. The resolution of the conflict would go beyond the creation of a nation-free or bi-national state, and demand for multiethnicization of politics and policy making on all levels.

The simplest solution to separate the "hostile" ethnic groups that guarantees a "negative" peace (based on "ethnicization" of politics and ghettoization of citizens from different ethnic backgrounds), according to some scholars, is a quick, but not a qualitatively satisfying solution (Vankovska 2014). Therefore, the Agreement aimed but failed to target all the roots causes of the conflict, such as the structural injustice and violence which were present in the societal context in the 1990s. Instead, it promoted the belief that a constitutional re-arrangement by itself would automatically eliminate the conflict in Macedonia. On the contrary, the expansion of its spirit way beyond the aspirations of peace agreements coupled with all-encompassing goals of development and international integration, protracted as well as hindered its implementation.

\section{Going forward - 17 years after Ohrid}

This year marks the $17^{\text {th }}$ anniversary of the Ohrid Framework Agreement. That allows for scholars and practitioners to evaluate Agreement's mediumterm outcomes. As it has been analyzed in the article, the implications of the Ohrid Framework Agreement transplanted into Constitutional amendments are complex and multi-pronged. These amendments initiated multivalent and diverse processes, which were contextualized by the particularities of the Macedonian society and political considerations. Even though those processes make devising a generalized conclusion 
difficult, the ex post facto analysis allows for some lessons to be drawn for future post-conflict constitutional redesigning.

Today, the Ohrid Agreement is one of the pillars of the Macedonian multiethnic social reality. All major political parties' platforms entail the goal for Macedonia to become an integral part of the European Union and NATO. In this sense, the Agreement represents a criterion for success of the reforms and a protector of minorities' rights. However, the Agreement has intrinsic flaws which hinder the process of its own implementation. As has been analyzed, the Agreement cannot be fully absorbed in the political system, neither by the criterion of its goals, nor by its over-reaching spirit which allows for free interpretation by political actors.

Several implications should be taken into consideration. First, in procedural sense, foreign terminology of agreements creates difficulties in the implementation of the provisions into the domestic legal system. Therefore, the language in peace agreements that entail constitutional redesigning should reflect the legalistic practice from the original constitutional framework. This can be done swiftly if the process includes local experts who would consult the process, adding value to the final draft. Even more, a direct transplantation of agreement's provisions into constitutional amendments undermines some procedural principles, such as, the independence of elected representatives, their right to vote and the process of law adoption. As was discussed in the article, agreements could, implicitly, institute a new harmful constitution amending procedure, through force and external pressure, contrary to the accepted principles of modern democracies. In that sense, agreements which purpose is to bring about developmental change, should not infringe established liberal principles. Peace agreements should set the stage for a process of institutionalized constitution redesigning, and serve as a driver for development of reforms and progressive democratic principles. Therefore, peace agreements should follow a phased approach, in which there will be steps for averting violence, institutionalizing conflict resolution, and forging a forum for constitutional redesigning.

Second, constitutional-institutional engineers should set the goals of the peace agreement realistically. If the approach of the peace process is mono-dimensional - stopping escalation and freezing violence - then 
internationally drafted agreements would suffice. However, if the goals include democratic development, internal and international integration, promotion of civil society and protection of minorities, peace agreements should take into consideration the intangible issues of political folklore, emotional tensions and historical imprints. Thus, if the social context is misunderstood or neglected in the post-conflict design, it can put ethnic lenses to its reading and implementation. That could load the implementation with emotions, prejudices, fear and stigma. For some authors, this happens because "...interests of implementers and evaluators are superficial and temporary, whereas the problems are long-lasting" (Orlovic 2015). Therefore, it is important for the agreement to entail realistic view of the capabilities of the affected society to substantially implement the provisions that have been negotiated. Then, the process of drafting and implementation of the agreement should include international actors, but also local scholars, experts, interest groups and societal stakeholders. In that manner, the process would allow for ownership both for the text of the agreement and for its implementation. The success of the arrangement can then be assessed by the ability of the societal actors to legally, politically and developmentally adhere to its provisions.

Third, if an agreement entails goals that go beyond achieving peace, then it should provide opportunities for conflict transformation - institutional mechanisms that transform the violent conflict into a developmental one. A constitutional reform cannot be successful if it does not set a base for dealing with the immediate triggers of the conflict and acute symptoms. In that sense, agreements should provide avenues for functional and structural power sharing, not a declarative power divide. The simplistic approach to separate and isolate the powers between conflicting parties leads to divergence. The gap that would be created leads to creating a society of bare tolerance, not of acceptance of the differences. In that sense, mediators' prowess would come to light if agreements are designed to target the conflict root causes and envision their management. Authors claim that a pure consociational or integrative approach cannot be implemented in practice, and pose dangers to multiethnic societies (Norris 2005, Samuels and Hawkins Wyeth 2006). Even systems that heavily relied on one or the other approach have failed significantly. Lack of success can be seen in the examples of Bosnia and Herzegovina and Lebanon which relied heavily on Lijphard's consociationalism, or Uganda 
and Fiji, which models were largely based on the integrative approach. Therefore, the answer in designing post-conflict constitutional systems should ask for meaningful power sharing, one that includes avenues for cooperation between the sides. Consociational models would set the basis for power sharing between the conflicting groups. In addition, the integrative governance would surpass the differences between the groups, by promoting cooperation in achieving the common goals. Those avenues would be the added value to the system that would lead to developmental changes. In essence, they should include full acceptance and promotion of ethnic diversity, extensive use of all languages, the creation of joint educational programs focusing on multiculturalism and inclusion of all minorities in the societal system.

The purpose of multiethnic societies is to promote and protect diversity, not to create separate and parallel systems. The answer to the question of conflict does not entail ethnically neutral approach. It lies in the creation of a multi-ethnical system where ethnicities' rights are respected, promoted and protected. The multiethnicism in Macedonian should act as its insignia, an example for the broader region and for future generations. That can be achieved if the Ohrid Framework Agreement is seen as a driver for the creation of a functioning multiethnic society oriented towards development and innovation, which respects the languages, the symbols, and the cultural heritage of all its members. Finally, the legal framework should assist the building of a societal system in which all ethnicities would sense their belonging and build their future. 


\section{Bibliography}

Ahrens, G. H. 2007 Diplomacy on the Edge: Containment of Ethnic Conflict and the Minorities Working Group of the Conferences on Yugoslavia. Washington, D.C.: Woodrow Wilson Center Press.

Beardsley, K., 2011. The mediation dilemma. Ithaca, N.Y.: Cornell University Press.

Bieber F., ed., 2008. Power-Sharing and the Implementation of the Ohrid Framework Agreement. Skopje: Friedrich Ebert Shtiftung Office in Skopje.

Constitution of the Republic of Macedonia, Number 08-4642/1, 17 November 1991, at http://www.sobranie.mk/the-constitution-ofthe-republic-of-macedonia.nspx [accessed 15 May 2017]

Crisis Group Europe Report N²12, 2011 , "Macedonia: Ten Years after the Conflict". http://www.crisisgroup.org/en/regions/europe/balkans/ macedonia/212-macedonia-ten-years-after-the-conflict.aspx [accessed 15 May 2017]

Crocker, C. A, Hampson, F. Osler, \& Aall, P. R, ed., 2005. Grasping the nettle: analyzing cases of intractable conflict. Washington, D.C.: United States Institute of Peace Press.

Czymmeck, A. and Viciska, K., 2011. A Model for Future Multi-Ethnic Coexistence? Macedonia 10 Years after the Ohrid Framework Agreement. KAS International Reports 11 |2011.

Hopmann, P. T., 1996. The negotiation process and the resolution of international conflicts. Columbia, S.C.: University of South Carolina Press.

ICG Balkans Report 109, 2001 "The Macedonian Question: Reform or Rebellion".

Jović, D., 2011. Bitka za etnički status u postjugoslovenskim drțavama. Političke analize, br. 5.

Lijphart, A., 2003. Modeli demokratije. Beograd i Podgorica: Sluzbeni list SiCG i CID. 
Maleska, M., 2005. What kind of a Political System did Macedonia get after the Ohrid Peace Agreement? New Balkan Politics, No.9-2005, on http://newbalkanpolitics.org.mk/item/What-kind-of-a-politicalsystem-did-Macedonia-get-after-the-Ohrid-Peace-Agreement\#. WYIOviUjHIU, [accessed 8 August 2017]

Norris, P., 2005. Stable democracy and good governance in divided societies: Do power-sharing institutions work? KSG Working Paper No. RWP05-014, on http://dx.doi.org/10.2139/ssrn.722626, [accessed 7 February 2018]

Ohrid Framework Agreement, 2001, http://www.ucd.ie/ibis/filestore/ Ohrid\%20Framework\%20Agreement.pdf.

Phillips, J., 2002. Macedonia: Warlords and Rebels in the Balkans. London: I.B. Tauris.

Samuels, K. and Hawkins, Wyeth V., 2006. State-building and Constitutional Design after Conflict, International Peace Academy, New York, on https://www.files.ethz.ch/isn/126785/state_building_consti_ design_08_2006.pdf [accessed 7 February 2018]

Skaric, S., 2004 "Ohrid Agreement and Minority Communities in Macedonia" In: Stanovcic V, Basic G. Prospects of Multiculturality in Western Balkan States. Ethnicity Research Center. Friedrich Ebert Stiftung.

Skaric, S. Siljanovska-Davkova G., 2009. Ustavno pravo (Constitutional law). Skopje: Kultura,

The Former Yugoslav Republic of Macedonia 2012 Progress Report, 2012, European Commission Staff Working Document.

Vankovska, B., The Role of the Ohrid Framework Agreement and the Peace Process in Macedonia on http://www.fzf.ukim.edu.mk/pdf/odb/ vankovska/Vankovska,\%20B.\%20-\%20The\%20Role\%20of\%20the\%20 Ohrid\%20Framework.\%20Agreement\%20and\%20the\%20Peace\%20 Process\%20in\%20Macedonia.pdf [accessed 15 May 2014]

Vasović, V., 2003. Lajphartova konsociaciona demokratija. Preface to the book, Modeli demokratije. Podgorica: CID.

Widner, J., 2008. Constitution Writing in Post-conflict Settings: An Overview, 
49 Wm. \& Mary L. Rev. 1513 on http://scholarship.law.wm.edu/ wmlr/vol49/iss4/16 [accessed 7 February 2018]

Yearly Report on the employed in the public sector, 2017. Skopje: Ministry of information society and administration on http://mioa.gov.mk/files/ pdf/dokumenti/Godisen_izvestaj_2016_Registar_na_vraboteni_vo_ JS.pdf [accessed 13 August 2017]

Zartman, I. W., 2008. Negotiation and conflict management: essays on theory and practice. London: Routledge. 
Stefan Andonovski (st.andonovski@gmail.com) holds a Master of Arts in International Relations and International Economics with Honors, from the Paul H. Nitze School of Advanced International Studies (SAIS), at the Johns Hopkins University. His focus of analysis is the field of conflict management, particularly contextualized to the region of the South-East Europe. He has been a participant and panelist at democratization and leadership seminars in Macedonia, Italy, Bosnia and Herzegovina, Hungary, Montenegro, Austria, Serbia, the Netherlands and the USA. He has also written opinion editorials concerning international mediation and negotiations, as well as constitutional reforms. Stefan's scope of interests includes bilateral and multilateral relations, democratization of multicultural societies, post-conflict reconciliation and justice. He is active in the civil sector and in youth policy-making. He fluently speaks Macedonian, Serbo-Croatian, English and Italian. In 2013, Stefan graduated in legal studies at the University "Ss. Cyril and Methodius" in Skopje. 